The Soul of Armies 
A VOLUME IN THE SERIES

Cornell Studies in Security Affairs

edited by Robert J. Art, Robert Jervis, and Stephen M. Walt

A list of titles in this series is available at www.cornellpress.cornell.edu. 


\section{The Soul of Armies}

Counterinsurgency Doctrine and Military Culture in the US and UK

Austin Long

Cornell University Press

Ithaca and London 


\section{Copyright ( 2016 by Cornell University}

All rights reserved. Except for brief quotations in a review, this book, or parts thereof, must not be reproduced in any form without permission in writing from the publisher. For information, address Cornell University Press, Sage House, 512 East State Street, Ithaca, New York 14850.

First published 2016 by Cornell University Press

First printing, Cornell Paperbacks, 2016

Printed in the United States of America

Library of Congress Cataloging-in-Publication Data

Long, Austin G., author.

The soul of armies : counterinsurgency doctrine and military culture in the US and UK / Austin Long. pages $\mathrm{cm}$ - (Cornell studies in security affairs) Includes bibliographical references and index. ISBN 978-0-8014-5379-3 (cloth : alk. paper) ISBN 978-1-5017-0319-5 (pbk : alk. paper)

1. Military doctrine-United States. 2. Military doctrine-Great Britain. 3. Counterinsurgency. 4. United States-Armed ForcesAttitudes. 5. Great Britain-Armed Forces-Attitudes. I. Title. II. Series: Cornell studies in security affairs.

U21.2.L66 2016

355.02'180941-dc23 2015032898

Cornell University Press strives to use environmentally responsible suppliers and materials to the fullest extent possible in the publishing of its books. Such materials include vegetable-based, low-VOC inks and acid-free papers that are recycled, totally chlorine-free, or partly composed of nonwood fibers. For further information, visit our website at www.cornellpress.cornell.edu.

Cloth printing $\quad 10987654321$

Paperback printing 10987654321

Cover photograph: Villagers talk to Afghan police and US soldiers near Qalat in Zabul province, Afghanistan, 25 March 2008.

REUTERS/Goran Tomasevic (Afghanistan). 